Sveučilište Josipa Jurja Strossmayera u Osijeku, Filozofski fakultet - Odsjek za filozofiju, Osijek, Hrvatska

DOI 10.5937/kultura1757223S

UDK 141.7 Арент X.

141.82 Сутлић В.

originalan naučni rad

\title{
KAKO MISLITIPRAKSURADA
}

\section{HANNAH ARENDT - VANJA SUTLIĆ - SUVREMENOST}

Sažetak: Suvremeni pristupi pojmu rada i praxisa imaju mnogostruke horizonte. Ovdje se polazi od aristotelovskog odnosa spram rada kod Hannah Arendt i njenog inzistiranja na istinskom ljudskom djelovanju, odvojenom od instrumentalnih odnosa. Kako god da je mislila rad, reducirajući ga na nuždu održanja života, kod nje je važno cjelovito shvaćanje prakse kao prostora različitosti, mogućnosti i slobode. Jedna od zagonetnih teza kod H. Arendt je kritika Marxova shvaćanja rada. Razlikovanje rada i proizvodnje, na tragu Karla Marxa, vrlo je istančano razvijeno kod Vanje Sutlića. U njegovim tekstovima pokazuje se da je istinska proizvodnja (kao productio) zapravo otkrivanje bitka koji se skriva iza otuđenja. Stoga je suvremeno shvaćanje čovjeka kao stvaralačkog bića temeljni moment osmišljavanja svijeta.

Ključne riječi: rad, proizvodnja, praxis, Hannah Arendt, Vanja Sutlić, Karl Marx

Klasične teze o radu kao muci i tlaci nisu ugasle nego su zadobile nova obličja. Današnji čovjek je deziluzionirani pripadnik tehno-znanstvenog poretka, sa svim svojim (ne)mogućnostima u ustrojenom svijetu, subjekt koji sebe u radu objektivira, ozbiljuje i otuđuje, u nezavršivom dinamizmu izmjeničnog oslobađanja i porobljavanja. Jesmo li slobodni? Nastojimo kako slobodovati, tako se i oneslobođavati, u gustom tkanju teško shvatljive i kompleksne uvjetovanosti. Suvremeni pristupi pojmu praxisa i svim njegovim dimenzijama imaju mnogostruka dna, odnosno neustanovljive bezdane u kojima se presijecaju pitanja slična arendtovskom orijentirajućem upitu: Što činimo kada djelujemo? Takvo pitanje zaista ima smisla samo ako se postavlja u pluralizmu (ili: poliarhizmu) vrijednosti, tj. ako priznamo da živimo u svijetu u kojem smo određeni fragmentarnošću i nedovršenošću zbilje. Suočeni s nedostatkom povjerenja u velike ideje dvadesetog 


\section{ŽELJKO SENKOVIĆ}

stoljeća (npr. napretka), ipak moramo nastaviti s propitivanjem 'radnog društva', smisla proizvodnje i ozbiljenja kroz djelovanje. Odgovori iz post-postmodernih načina mišljenja nekada su inspirativni, a katkada kao da pozivaju na sučeljavanje s konceptom 'povijesnog mišljenja', pri kojem nije presudna aktualna novost teorije/pristupa, nego uvid u istinski suodnos onoga što je bilo, jest i može biti, zbog uvijek nove teorijsko-praktičke konstelacije, a ono što shvatimo i postuliramo trebalo bi biti mišljenje u "tvorbi zajednice i proizvodnji svijeta iz kazivanja našeg neponovljivog zbivanja povijesti". 1

Razlikovanje između rada i proizvodnje odgovara razlici prirode i svijeta. U jednom području Ja se uspostavlja i zaista postoji, u drugo područje sklanjamo se kako bi održali naše biološko biće. S obzirom na ovo, ma kako glorificirali rad, koliko god ga u modernom dobu protegnuli na sva djelovanja (i pisac kaže da radi, violinist ide raditi i odraditi svirku i sl.), rad ima cikličku strukturu koja odgovara životu prirode. Ta je struktura kod Arendt povezana sa potrošnjom. K tome, kod Arendt je proizvođenje otvaranje Ja prema svijetu. Govoreći o svom ranijem radu, Arendt $\mathrm{u}$ The Life of the Mind, kaže:

"U knjizi Vita activa u kojoj sam se bavila životom provedenim u delovanju, posebno me je interesovalo kako to da se suprotna ideja potpunog mira koji donosi vita contemplativa toliko nametnula da u poređenju s tim mirom sve razlike među raznovrsnim aktivnostima vitae activae nestaju. U poređenju s njim, više nije važno da li obrađujete zemlju, ili proizvodite upotrebne predmete, ili delujete s drugima u nekim zajedničkim poduhvatima. Čak i Marks, u čijem delu i mišljenju pitanje delovanja ima tako značajnu ulogu koristi pojam praxis da bi označio ono šta čovek radi nasuprot onome šta misli”. ${ }^{2}$

Vita activa (ili Amor mundi, kako je prvotni, zamišljeni naslov te knjige) stoji na tragu raščaravanja metafizike i prekidanja s tradicijom. To djelo je posvećeno razumijevanju djelatnog čovjeka (onome što činimo kada djelujemo), a već je taj prvi i temeljni odredbeni smisao horizont aristotelovski. Naime, aristotelovski mišljeno u pravom smislu jesmo kada smo djelatna bića; energeia se može ispoljavati u tri načina života: bios theoretikos, bios politikos i bios poietikos. U svim tim modusima bivstvovanja

1 Sutlić, V. (1994) Uvod u povijesno mišljenje, Zagreb: Demetra, str. 152.

2 Arent, H (2009) Život duha, Beograd: Službeni glasnik, str. 19. Što se tiče Arendtičine kritike Marxa, prema njoj je Marxov paradoks u tome što njegovo shvaćanje proizvodnje ostaje u okviru anti-političke (platoničke) filozofske tradicije. Zašto je tome tako? Moderni filozofi više su teoretičari društva nego politike. U smislu kako Arendt shvaća političko, Marx nije u istinskom smislu političan, jer se prvenstveno zanima ekonomskim analizama i raspodjelom društvenog bogatstva. 


\section{ŽELJKO SENKOVIĆ}

može se ispoljavati narav čovjeka, tj. logosni moment psyche kao mjesto harmonije i jedinstva svega. Aristotelovska logocentričnost stoljećima je određivala mnogostruke pravce zapadnjačke racionalnosti, sve do (post)modernih inverzija iste. U tom smislu, dekonstrukcija logocentričnosti (metafizike), bilo u izvedbi Jacquesa Derridae ili Hannah Arendt, nikada nije jednostavna jer filozofske kategorije nastavljaju određivati fundamentalni način našeg uvida u svijet.

Kako je prevladavanje metafizike (pogotovo kada se odvija zaobilazno u odnosu spram epohalnog Kantova poduhvata) uvijek u opasnosti i preuzetnosti proturječja (jer je povijest filozofije u osnovi povijest metafizike), pa u nedostatku leksike i sintakse koja bi bila izvan te tradicije često je na djelu fokusiranje na neki aspekt egzistencijalnog i djelatnog sklopa. Tako je i kod Arendt u Vita activa primarno ponuđena dijagnostika našeg suvremenog otuđenja: mi smo u svojevrsnom 'zaboravu praxis'. Ovu je sintagmu Dana Villa ponudio ${ }^{3}$ kao tumačenje arendtovske kritike suvremenog zanemarivanja javnog i političkog područja od strane mainstream filozofskih pravaca. Aluzija na znameniti heideggerovski 'zaborav bitka' je naravno snažna, ali je možemo transcendirati tako da je uzmemo kao odskočnicu za posve drugačiji teorijski okvir.

Arendt voli analogije i alegorije, posebice su joj drage reference na moderno stanje. Njena slika o putovanju u svemir kao znamen modernog otuđenja od svijeta dramatičnija je nego što čitatelj u svojoj prvoloptaškoj reakciji sluti. No modernost karakterizira i bijeg iz svijeta u sebstvo. Ovo je pak oblik unutrašnjeg egzila, pri čemu individualno sebstvo odbacuje zajednički, ljudski svijet. Romantizam (od kraja 18. stoljeća do u prvu polovicu 19. stoljeća) formirao je i odredio razvoj modernog društva, erodirala je sloboda javnog i političkog područja, što je pripremilo epohu konformizma i konzumerizma. Romantički autori (npr. pjesnik William Wordsworth, 1770-1850), snažno su naglašavali vrijednost intimnosti i samotnog umjetničkog stvaralaštva. Arendt shvaća Rousseaua kao protivnika: on je imao negativan utjecaj u smislu kako ona tumači ključno otuđenje suvremenosti: svjetsko otuđenje ili otuđenje od svijeta. Ono ima korijene još u platoničkom ili srednjovjekovno-teološkom tezariju, ali je posebice preko romantizma i kroz tehno-znanstvenu civilizaciju pripremilo put za vladavinu mase i pojavu totalitarizma.

Otto Pöggeler upozorava na više mjesta o isprepletenosti mišljenja H. Arendt i M. Heideggera. Isto se vidi i u njihovom

3 Usporediti: Villa, D. R. (1996) Arendt and Heidegger. The Fate of the Political, Princeton: Princeton University Press. 


\section{ŽELJKO SENKOVIĆ}

zajedničkom odbijanju tzv. praktičke filozofije. ${ }^{4}$ Naime, dok je ta sintagma za Arendt nešto gotovo proturječno s obzirom na njenu tezu da je glavnina zapadnjačkih mislilaca određena zaboravom praxis, dotle je za Heideggera vrlo važna distanca spram bilo kakve simbiotike konkretne filozofske discipline i 'izvornog mišljenja'. Prema Pöggeleru, Arendtičino pitanje o istinskom bivstvovanju, s obzirom na propitivanje onoga što je bio grčki polis, mora se dovesti u vezu sa Heideggerovim tumačenjem Aristotela. Aristotelovsko shvaćanje praxisa (suodnosa theoria i praxis), samo je okvir u kojem se kod Arendt razvijaju mnogobrojni uvidi, od kojih se Heidegger, zbog njihove 'konkretnosti' i hibridnosti zasigurno sklanjao. Dok se kod Heideggera svakodnevlje emfatično veže uz fluidnost onoga das Man (bezlično Se), Arendt se opredjeljuje za pluralitet kao istinskost što će transcendirati kako pravocrtne tehničke zadanosti modernog društva, tako i atavističke koncepte predmodernih filozofema. Naravno, problematično je što Arendt koncept zajedničkog djelovanja (Action) odvaja od rada (Labor) i proizvođenja (Work), pa bi društveni problemi tako postali tehničkim pitanjem, a ne horizont za istinsko političko optiranje. Dok se Heidegger pitao o tome koji bi politički koncept odgovarao tehno-znanstvenokibernetičkom dobu svijeta, Arendt se otvara konceptu pluralnosti, ali kao da je sa Heideggerom zapravo dijelila zajednički ton (ugođaj, uštimanost) za prvenstveno 'negativno' čuvstovanje duha vremena (Zeitgeist). Naime, Arendt se distancira od suvremenih događaja te konstantno naglašava razboritost i prosudbu (phronesis $\underline{i}$ Urteilskraft). Ono što nam pak kao građanstvu svijeta nedostaje, teško je dostižno. Nije riječ o tome da uski krug intelektualne i umjetničke elite više diskutira i stvara, nego o potrazi za novim osvjetovljenjem čovjeka kojem je kao građaninu orijentir da svijet iznova učini političkim.

Ukoliko je problem (i) filozofija, Platon je krivac nad krivcima. "Upravo filozofija, koja je htjela izgraditi jednu političku filozofiju a filozofe postaviti za kraljeve, ima mjerodavan udio u tom razaranju političkog. Hannah Arendt preuzima tehničku interpretaciju Platonovog nauka o idejama, kako ju je oblikovao Heidegger (zanatlija najprije vidi ideju, potom prelazi na čin; tako se, pak, razara zajedničko djelovanje u javnom području. Znanost i tehnika - kakve je razvilo novo stoljeće - konačno su ostvarili tu postavku [...] Suglasnost između Heideggera i Hannah Arendt sastoji se u tome da nije moguća politička filozofija koja, polazeći od uvida u ideje, upravlja djelovanjem". ${ }^{5}$

4 Usporediti: Pöggeler, O. Heidegger u svom vremenu, Sarajevo: TKD Šahinpašić, str. 129-131.

5 Isto, str. 132. 


\section{ŽELJKO SENKOVIĆ}

Kod Arendt, moderno djelovanje je nadomješteno proizvođenjem i radom, u sve pore ljudskog postojanja zavlači se ekonomski model: sveprožimajuće kalkulacije i profiti odavno određuju ljudske odnose, sve djelatnosti su srozane na rad, a metafizika je umnogome utjecala na tehničko disponiranje svijeta (npr. Hegel i filozofiju shvaća kao rad - rad pojma). Navedeno se može shvatiti i u horizontu osnovnih postavki uglednog njemačkog filozofa, Otta Pöggelera. Ovaj znameniti tumač fenomenologije i napose Heideggera, olako kritizira temeljne postavke knjige Vita activa. Naime, kada ustvrdi ${ }^{6}$ da Arendtičino tumačenje prakse povređuje odnos spram prirode u koji se moramo uklopiti ili da njene distinkcije rada i proizvodnje povređuju fenomene, to nije ništa drugo nego teza s kojom se u ishodištu tvrdi da svaki autorski stav možemo na neki način eskivirati samo ako naznačimo drugačije problemske i metodske horizonte. Smatram da Arendt ne 'presijeca' odnos spram prirode, nego ga ustrojava u aristotelovskom postavu, a mnogo puta iskazana kritika spram rigidnosti njene trodiobe vita activa (rad, proizvodnja, djelovanje) gubi oštricu pred smislom takvog poduhvata: odijeliti istinsko ljudsko djelovanje (u čistoći njegove samosvrhe) od svih instrumentalnih odnosa u koje nas stavlja 'svinjski polis' (grč. polis porkos). Često je isticana teza da njeno usko shvaćanje djelovanja kao sukusa političkog ne odgovara zbilji suvremenosti, no riječ je zapravo o tome da je projekcija djelovanja koje će imati istinski prostor slobode višeslojna: ona je kritika postojećih otuđenja, poziv na povijesno mišljenje i orijentiranje, zazivanje doba svijeta iz kojega ćemo konačno iskoračiti kao iz 'mračnog doba'. Dvadeseto stoljeće otvorilo je premalo vremena/prostora za ono što je procvjetalo u europskom osamnaestom stoljeću; mračnost naše epohe je kao neka regresivna evolucija: propadanje u prošla vremena u kojima je Drugost bila neprepoznata, a svjetlost umjetnosti i znanosti slabašna. Stoga je ovdje riječ o traženju ireduktivnih referentnih točaka istinski ljudskog na koje će se magnetski skupljati žar velikih potraga prošlosti i nada budućnosti, kako bi se othrvali instrumentalističkim postavima tehno-znanstvene epohe u koje propadamo zbog neodrživog odnosa spram prirode u sebi i srozavanja politike na tehniku. U tom smislu, ako filozofiju i svako bitno mišljenje ne prosuđujemo 'od vrha', od smisla do kojeg joj je stalo, naveliko promašujemo.

Mnoštvo je smjerova iz kojih se može kritizirati Arendtičina podjela vita activa, od weberijanske do neomarksističke perspektive. Mnogima je ta podjela odveć gruba, čini se da se zanemaruje bilo kakva preklapajuća i dijalektička veza između područja nužde i slobode. Aristotelova hijerarhija djelatnosti

6 Isto, str. 134. 


\section{ŽELJKO SENKOVIĆ}

rada, djelatnosti proizvođenja i djelatnosti djelovanja kao da $\mathrm{u}$ konačnici osigurava prostor slobode samo za manjinu, tj. kao da je Arendtičino shvaćanje politike odveć ekskluzivističko u redukcionizmu spram mnogih aktivnosti koje smatramo važnim za ljudskost čovjeka. O čemu je tu riječ?

U traženju samodostatne slobodne djelatnosti, s onu stranu instrumentalističke usmjerenosti, Arendt pokušava nadići momente suvremene politike koji joj se ne čine izrazom otvorenosti (i) slobode. Umjesto smislotvornosti, suvremena politika je tehnika preživljavanja, socijalnog uštimavanja i pukog pragmatičkog kalkuliranja. Kada je primarno socijalno pitanje (od radnog do karitativnog aspekta, npr.), na djelu je biologiziranje i reprodukcija. Naravno, životni proces nije nebitan, izlišno je ustvrditi da iz brige za pojedinca i vrstu proishode one uistinu ljudske aktivnosti, ali bivanje u njemu je - prema njenom (ipak) grekofilskom orijentiranju - ostajanje u (cum grano salis) predljudskom trajanju.

Također, za hegelovsko-marksističku tradiciju razlikovanje rada i proizvođenja nije samorazumljivo. U najboljem slučaju moglo bi se reći da ta distinkcija nije dovoljno naglašavana. Ono što je za Arendt referentna točka razlikovanja proizvođenja spram rada jest svrhovitost, koja je imanentna dugotrajnijim proizvodima proizvođenja, za razliku od jednokratnosti proizvoda rada. Rezultat proizvođenja razlikuje se od cirkularnosti i nužnosti radnog procesa. Umješnost ili umijeće, spravljanje i(li) sačinjanje, sve od činjenja obrtnika do tvorbe umjetnika, imaju specifičnu poziciju u području vita activa koja se može istumačiti referencom na Aristotela:

"Umijeće se ne bavi onim stvarima koje jesu ili nastaju po nužnosti, niti pak onima što su takve po naravi; time je počelo u njima samima. I budući su, dakle, tvorba i činidba različite, nužno je da umijeće bude tvorba (poiesis), a ne činidba (praxis)".?

Dakle, proizvođenje nije po naravi nego je neka vrsta nasilnosti, usuprot prirodi. Postvarenje ili reifikacija ne pronalazi put unutar prirodnog procesa rasta i propadanja, nego usprkos i izvan njega. Stabilnost ljudskog života tek je omogućena ovakvim izlaženjem iz stalno obnavljajućeg prirodnog ciklusa. Ona u sebi ima negativitet koji nije posredujući element u hegelovskom smislu. Drugačije od toga (jer nije 'druga narav'), taj negativitet kod Arendt svojom ne-prirodnošću otvara prostor za ljudski svijet. Proizvodi proizvođenja stoje između prirode i humaniteta (u strogom smislu). Ovo je pak u konačnici uspostavljanje

7 Aristotel (1992) Nikomahova etika, Zagreb: Hrvatska sveučilišna naklada, str. 117. (EN VI 4, 1140 a 14-17). 


\section{ŽELJKO SENKOVIĆ}

hijatusa između slobode i nužnosti, premda svijet uspostavljen proizvodnjom nije po sebi područje slobode; štoviše, njegova instrumentalnost ponekad se čini bližom 'uzaludnosti' radnog procesa. Međutim, ukoliko je netrajnost radnog procesa istoznačna ispražnjenosti od smisla, instrumentalnost procesa proizvođenja lišava je neovisne vrijednosti. Ova je razlika značajna.

Vanja Sutlić, mislilac kojeg uobičajeno svrstavaju u nasljedovatelja Marxa i Heideggera, premda je takvo klasificiranje umnogome promašeno, posebice je važan s obzirom na tematiku praxisa (a ovdje to u konačnici znači: odnosa spram proizvodnje, rada i stvaralačke tvorbe svijeta) jer čini neke ontologijske diferencije s obzirom na smisao rada i proizvodnje. On uočava ${ }^{8}$ da Marx u nekoliko svojih tekstova: Ekonomsko-filozofijski rukopisi i Njemačka ideologija otuđenu ljudsku svijest naziva radom, a njeno slobodno ispoljavanje proizvodnjom. Nažalost, Arendt je upravo zanemarila distinkciju proizvodnje i rada iz horizonta smisla onoga do čega je bilo stalo Marxu. Kada Arendt kod Marxa pronalazi proturječja ${ }^{9} \mathrm{~s}$ tezom se kod njega traži prevladavanje rada kao otuđenja, a da je čovjek istodobno shvaćen kao radno biće, na djelu je prilično nediferencirano čitanje Marxa. Stoga je instruktivno uvidjeti kako Vanja Sutlić iz perspektive nastojanja oko povijesnog mišljenja pristupa pojmu prakse kod Marxa. Njemu je prioritetno razmatranje bitka (biti) čovjeka, odnosno njegovo razlikovanje od bitka stvari. Prema Sutliću, kod Marxa postoji razlika između proizvodnje kao slobodne ljudske djelatnosti, kao biti čovjeka (generičkog života), kao svjesne životne djelatnosti i rada kao otuđenja ljudske djelatnosti, kao apstraktnog rada koji tvori robe, kao rada koji je stvar među stvarima. ${ }^{10}$

Ma koliko se suvremeni uvidi u bit rada i radnika razvijali u smjeru kibernetičkog tehno-znanstvenog postava i mnogovrsnih uvida u zapalost naše epohe, Marxovi uvidi stoje kao epohalna prekretnica. Premda je od njegova vremena radikalno izmijenjena realna ekonomija, još uvijek je važna njegova kritika političke ekonomije, koja se zasniva na "razlikovanju proizvoda ljudskog rada od formalnih robnih i društvenih pretpostavki njihove proizvodnje". ${ }^{11}$ Što su stvari, što je roba, kakvi su preduvjeti proizvodnje, povijesno je uvjetovano. U konačnici, ideologijskim prividom u vezi naravi robe prikrivaju se društvene

8 Usporediti: Sutlić, V. (1972) Bit i suvremenost, Sarajevo: Veselin Masleša, str. 44 etc.

9 Usporediti: Arendt, H. (1991) Vita activa, Zagreb: Biblioteka August Cesarec, str. 67-109.

10 Usporediti: Sutlić, V. (1972) Bit i suvremenost, Sarajevo: Veselin Masleša, str. 23-31.

11 Usporediti: Rodin, D. (2012) Poraz prosvjetiteljstva, Zagreb: Naklada Breza, str. 35 . 


\section{ŽELJKO SENKOVIĆ}

nejednakosti koje generira robna forma. Marx je smatrao da ljudi vladaju nad ljudima pomoću vladavine nad stvarima. S obzirom na navedeno, Sutlić promišlja konstituense ljudskog u vezi s pojmom odnosa, a pojam odnosa otvara horizont otvorenosti same (jer i bitak je odnos, prema Sutliću), u smislu da se istinska bit čovjeka kao bića odnosa pokazuje kroz njegovu stvaralačku (proizvodnu) djelatnost.

"Svi oblici otuđenja proizlaze iz rada kao specifičnog odnosa $\mathrm{k}$ bićima u njihovoj sadašnjosti, realnosti, prisutnosti, aktualnosti, ili, što je isto, iz rada kao djelatnosti čiji je cilj proizvodnja roba [...] U otuđenju je samstvo (Selbst) nemoć, trpljenje, rad kao djelatnost usmjerena protiv čovjeka, a drugi čovjek gospodar nad čovjekom radnikom. Temeljno otuđenje je pervertiranje proizvodnje bića iz bitka u rad koji stvara robe". ${ }^{12}$

Kroz diferenciju proizvodnje i rada vidi se razlika između marksizma i pragmatizma, novovjekovnog aktivizma i Marxova shvaćanja prakse. U odnosu spram bića (i stvari) čovjek se ne mora samo otuđivati i dehumanizirati, nego se može i afirmirati u odnosu spram njih. Prozvodnja (sutlićevski: pro-iz-vodnja bića iz bitka) nije 'svakodnevna zapalost' (alltägliche Verfallenheit), kako to stoji kod M. Heideggera, nego to, prema Sutliću, važi samo za otuđeni rad koji ne treba identificirati s proizvodnjom.

Svijet se danas drugačije razdjeljuje i ustrojava nego ranije. U postkolonijalnom svijetu današnjice, kapitalizam je metamorfozirao u globalizam. Informacijsko doba na drugi način određuje prostor-vrijeme, ekspanzija i dostupnost se uspostavljaju drugačije, restrukturacija društvenih procesa i odnosa nadilazi sve ranije poznate odnose. Umjesto nekadašnjih prirodnih granica, moderno doba ima wi-fi domene, informacijsku tehnologiju i složene reprodukcijske lance koji umnažaju potrebe od smisla ispražnjenog čovjeka. Radni i proizvodni odnosi intenziviraju se u formama modernog robovanja (potplaćeni i prekarni rad etc.). Nestanak javnog prostora proizveo je nestanak suverene države, tradicionalna/konzervativna tumačenja naše situacije više ne mogu pratiti hektične mijene u kojima jesmo. Suvremene krize nepovratno i korijenski mijenjaju jezik i značenjski sklop kojim dijagnosticiramo novu reprodukciju života.

Ako je danas na djelu kriza kapitalizma, što nam to govori o praksi? Kao prvo, Marx je o krizi kapitalizma govorio na imanentan način, predviđajući njegova entropička urušavanja. Budući da se kapitalizam (vjerojatno) ipak ne urušava nego transformira (urušavajući zadnje oaze slobode i ljudskosti), zapravo

12 Usporediti: Sutlić, V. (1972) Bit i suvremenost, Sarajevo: Veselin Masleša, str. 30 . 


\section{ŽELJKO SENKOVIĆ}

prvenstveno nestaje smisao praxisa. O sadašnjoj krizi kapitalizma kaže se pak ${ }^{13}$ da je "eksterno generirana". Kapital više ne upravlja mikro-elektronskom tehnologijom. Profitna stopa, kako je Marx predviđao, nije smanjena nego prebačena u financijski sektor. Financijama upravljaju banke koje ne ostvaruju profit posredstvom proizvodnje dobara nego kroz kamatu na kreditirani novac. Kada je Marx kritizirao političku ekonomiju, uopće nije činio distinkciju kapitala na industrijski i financijski. Njegovo shvaćanje kapitala je takvo da kapital kontrolira svoje financije. No s jezikom tradicionalne ekonomije ne može se doći do odgovarajuće semantike suvremene ekonomske krize. U važnim svjetskim bankama novac ne potječe samo iz standardne akumulacije viška kapitala, već i iz plasmana fiktivno kreiranog novca. Financijske institucije se vrlo 'slobodno' (da ne kažemo mutnim teorijskim izrazom: 'liberalno') odnose spram kapitala. Prema D. Rodinu ${ }^{14}$ danas prevažnu ulogu ima hibridni novac, koji je ili fiktivni novac ili je nastao proizvodnjom inovacija u mnogim modernim sektorima. Kroz nove oblike reprodukcije stvara se nova konkurencija i nova znanja. Ona opstoje paralelno uz starije oblike reprodukcije. Među njima se događa sukob, ali i nužda međusobnog toleriranja jer bi naglo i umjetno istiskivanje jednog sektora prouzročilo socijalnu katastrofu za ogroman broj ljudi.

Ali što je alternativa? Umjesto revolucije, suradnja? Dok se moderni inovativni sustav i know-how sustavi u pravilu nalaze $u$ bogatijim državama, tradicionalna industrijska proizvodnja pretežno je u nerazvijenom svijetu. Ovaj prvi sektor koristi se kompjutorskom kontrolom takva novca, permanentnim variranjem kamatnih stopa, jeftinim ili skupim kreditima, otpisima dugova zbog budućih ekstra profita. Financijsko poslovanje banaka je strogo kontrolirano i programirano. Stoga je ono što zovemo neoliberalizmom sustav neslobode. Radnici su danas umnogome opterećeniji nego ikad prije, ali financijske institucije i kreditori ne isisavaju više direktno rad i radništvo, nego profit od kapitala. Proizvodnja profita je umjetno generirana, diljem svijeta velika poduzeća su pod teretom otplate skupih kredita. Plasmani fiktivnog novca propadaju, nisu industrijski oplođeni, a rezerve realnog novca u bankama ne mogu pokriti gubitke plasmana fiktivnog novca. Kapital se više ne reproducira autonomno. Razmjeri mogućih socijalnih kriza s obzirom na ovakvu krizu kapitala ne mogu se predvidjeti. Sve produktivnije i skuplje tehnologije generirat će nezaposlenost. Paradoksalno, industrijski rad ugrožen je i inovativnim radom, koji se ne mjeri vremenom

13 Usporediti: Rodin, D. (2012) Poraz prosvjetiteljstva, Zagreb: Naklada Breza str. 199 etc.

14 Isto, str. 202 etc. 


\section{ŽELJKO SENKOVIĆ}

provedenim u specifičnoj djelatnosti rada. Nadrealna i fiktivna, neljudska i strogo determinirana, suvremena ekonomska recesija je bez presedana. Zato je potrebno tražiti balanse i usuglašavanje ovih različitih paradigmi, nužnih za nove sprege da bi se izbjegle tragedije za egzistenciju milijuna ljudi koji privređuju u tradicionalnim oblicima proizvodnje.

“Globalizam nije izvorni fenomen, već popratni efekt razvoja te nove tehnologije. Ona bez ratova, kolonizacija, osvajanja, pokoravanja, zatiranja razlika premošćuje prostore i vremenske, političke i druge granice tradicionalnih kultura i životnih oblika ne uništavajući ih, već pretvarajući ih u nove životne resurse". ${ }^{15}$

Hoće li se i kako dogoditi kooperacija (su-radnja) različitih oblika proizvodnje, pod vidom života i smisla a ne logikom kapitala, danas je tek tamna slutnja u sjeni sve izglednijih katastrofa. U slučajevima istinskog produktivnog djelovanja globalizacije na tradicijske kulturne i klasične oblike proizvodnje, događa se afirmativni pristup životu, novi izvor života (smisla), što u pravilu znači izbjegavanje logike kapitala kao prve i prvenstvene redukcijske orijentacije. Semantičke relacije starijih i novijih načina življenja (stvaranja) jedina su racionalna alternativa prijetećim društvenim katastrofama.

Ovo istodobno prati i potreba policentričkog političkog uređenja. Ako je demokracija prvenstveno projekt, sveriječ koja se fluidno rasplinjuje, ograničimo li je sadržajno (primjerice: socijaldemokracija, liberalna demokracija itd.) uvijek joj nešto uzimamo od potencijalnosti (mogućnosti) u kojoj je zapravo njena bit. To da demokraciju treba misliti polazeći od njene autopoietičnosti, u smislu da pretpostavimo ključne dosege političke suvremenosti kao što su vladavina prava, zaštita manjina, stalno produciranje i omogućavanje diskursa u formi pozicija-opozicija, onda možemo pretpostaviti njenu dynamis koja nije iscrpiva ili primarno fokusirana na ono 'kratein' (vladati) u 'demokratia', nego je prostor otvorenosti i regulativni horizont sebeodređenja građanina.

Demokracija je poželjan medij za permanentno civiliziranje kultura i svakovrsni boljitak građana. Staro i novo, oni koji imaju više i oni koji su potrebiti, pitanja jednakopravnosti i vječno vraćanje neravnopravnosti načelno jednakopravnih, vječna su pitanja života demokracije kao dinamičnog i otvorenog bivstva građanina. Demokracija je prošla mnoge povijesne promjene, čini se da je svagda bila krhka i podložna ruiniranju od strane interesnih klika (uvijek je postojala oligarhija, a današnji moderni oligarsi imaju višestruke demokratske, u pravilu legitimne,

15 Isto, str. 212. 


\section{ŽELJKO SENKOVIĆ}

krinke), generirajući razliku vladajući-vladani. Budući da su kroz povijest bili iskušani mnogobrojni modeli, premda se metamorfozirajući vraćaju kao sablasti onoga što je takoreći upisano u čovjeka kao biće koje često promašuje a rijetko pogađa smisao i dobrotu, preostaje samo se nadati otvaranju putova solidarnosti a ne obnavljanju nekog kanibalskog društvenog procesa, u kojima su jedine konstante kapital i moć što se besmisleno umnaža proizvodeći bijedu i očaj za mnoštvo. Isključeni, odbačeni i prezreni, oni koji nemaju šanse za tzv. tržište rada, pokazatelj su da ono što danas nazivamo demokracijom često samo omogućuje oligarsima da vladaju "u ime naroda", te da kroz kibernetički ostvareno društvo spektakla uspostavljaju vlast nad javnošću. Dominacija i preobilje jednih, bijeda i izolacija drugih. Isto uništava pluralizam i različitosti, a mišljenje različitosti i uvažavanje razlika ono je što ne možemo prenaglasiti. Budući da demokracija treba ostvarivati različitosti i širiti prostor slobode, upitno je zašto intenzivno stvara plutokrate i oligarhe? Moj odgovor je da ljudskost treba misliti kao šarolik i vrlo ekstenzivan snop mnogostrukih uvjetovanosti i nagnuća ka zlu. Na prvi pogled ovo implicira svojevrstan antropološki pesimizam. No teoriju i praksu, mišljenje i život, ne trebamo locirati oko kratkovidnog pesimizma ili optimizma, nego ustrajati na mogućnosti uvijek iznova ostvarive svjetovnosti svijeta. To je jedina istinska izvorna dimenzija ljudskosti, koja nikada neće zastarjeti, ma koliko i kako intenzivno doživjeli rezignaciju i neuspjeh u realnim odnosima i društvu.

Moderna distinkcija je u tome da su privatni interesi postali javna briga, zatamnjeno je klasično razlikovanje javnog i privatnog područja. Ma koliko se takav stav činio nemodernim, to je jedna od ključnih arendtijanskih referenci, čijim (pre)naglašavanjem želi istaknuti mogućnost stremljenja svojevrsnoj 'čistoći' u 'dijeljenju riječi i djela', s onu stranu biološko-ekonomsko-tržišnih momenata. Javno područje treba imati svrhovitost u sebi, jer je čovjek zoon logon echon. To što mi više za to nemamo politički sluh, znamen je zapalosti i otuđenosti naše epohe. U tom smislu, mnoge radikalne kritike moderne conditio humana, kao što je marksistička, ne dolaze do temeljnog uvida u problem prakse. Stoga je njen rad pokušaj prekida s prevladavajućom tradicijom i propitivanje zamrlih ljudskih mogućnosti slobodovanja. Također ona optira za pluralizam. A pluralnost je drugo ime za drugačijost, za mogućnost istinskog mišljenja kao prosudbe i uvažavanja mnogovrsnih stajališta Drugih, za ljudskost koja nije zatvorena u jednodimenzionalni ideologijski obrazac (ili kojigod drugi nemisleni i neosobni diktat ustrojenog svijeta).

U priključku na Aristotelovu Politiku, Arendt određuje rad kao zajedničku nužnu aktivnost ljudima i životinjama. Stoga je rad 


\section{ŽELJKO SENKOVIĆ}

najmanje distinktivna ljudska aktivnost, a k tome je kroz povijest bila prvenstveno vezana uz tijelo, činjena u privatnosti, njegova nužnost je druga riječ za prirodnost koju čovjek kroz aspekt animalnosti dijeli sa drugim živim bićima. Rad jest nužda, što znači da će ga biti dok bude ljudi, pa i u arendtijanski diferenciranom i reduciranom određenju. Međutim, problematično je zauzimanje svih ljudskih područja od strane animal laboransa, koji izvorno privatne aktivnosti prezentira u nestajućem javnom području. Život u praxis iščeznuo je, a metabolički procesi su isključivi fokus medijske sfere. U dobu 'slike (bez) svijeta' na djelu su katastrofalne metamorfoze, pa ovakvi zazivi izvornog razumijevanja prakse nisu jednostavno nemoderni i reakcionarni, nego radikalna fenomenologijska kritika konzumerizma, pukih bioloških i privatnih interesa, emancipacije rada kao takvog (što nipošto nije istoznačno s radničkom klasom) i njegovog presezanja na sve ljudske aktivnosti. Čovjek je zoon politikon, društveno biće, tj. biće koje konstantno može i treba nadilaziti ne-slobodu i zadanosti biologičnosti svojeg bića. Stalno se oneslobađamo i to je naprosto normalni aspekt našeg života. No također se i oslobađamo, i to već uvijek kada isto tek pokušavamo, kada jesmo sloboda a ne da samo 'imamo slobodu' etc. Dinamizam slobode i neslobode druga je riječ za dinamizam širokog spektra ljudskosti. Vođen vizijom istinske ljudskosti, Arendtičin pogled je distingvirao područje ljudske djelatnosti.

Kod Sutlića rad postaje Rad; umjesto Hegelove Ideje (koja je pala u vrijeme), to je novi apsolut, ujedno i epohalno određen. Upravo je pojam rada kao dio šire sintagme 'praksa rada kao znanstvena povijest' jedna od najinovativnijih sintagmi na našem (misaonom) području. Čovjek je praktičko biće, tj. praksa (kao najviši oblik theoria u aristotelovskom smislu) jest bit čovjeka. Budući da je bit čovjeka vremenita, filozofija to vidi kao povijesnost. U tom smislu, čovjek je "povijesni proizvod kao i sva druga bića", ${ }^{16}$ ali osim što je proizvod, on je i proizvoditelj: “...cjelokupna tzv. svjetska povijest nije ništa drugo do proizvodnja čovjeka pomoću ljudskog rada". ${ }^{17} \mathrm{~S}$ ovim određenjima čovjek se stavlja u dispozitiv samostvaranja, slobode i proizvodnje. Čovjek je vlastito djelo, kroz djelovanje stvara sebe samoga budući da proizvodnja nikada nije samo proizvodnja materijalnih ili duhovnih (mnogovrsnih ne-materijalnih proizvoda u uobičajenim, standardnim odredbama), nego se čovjek proizvodeći odnosi spram punine i cjeline onoga što jest, ne odnoseći se tek na bića nego na bitak (tj. na otvorenost spram mogućnosti vlastitog ostvarenja).

16 Sutlić, V. (1972) Bit i suvremenost, Sarajevo: Veselin Masleša, str. 19.

17 Marx, K (1953) Rani radovi, Zagreb: Naprijed, str. 237. 


\section{ŽELJKO SENKOVIĆ}

Ako se čovjek kao biće prakse kod Marxa i Sutlića u novovjekovnoj povijesti mnogovrsno otuđuje (na Marxovo četverostruko otuđenje rada nadovezuju se mnoga druga suvremena otuđenja), prvo otuđenje je otuđenje proizvodnje u (ne-stvaralački) rad. Proizvoditelj je pri-seban, ozbiljuje svoju bit, samodjelatan, zbiva se u sebi, ostvaruje se. Novovjeka situacija je pak par exellence situacija otuđenja. To je horizont koji naglašava distinkciju proizvodnje i rada, budući da je proizvodnja (kao istinski i smisleni rad) aktivnost kojom se uspostavlja bit čovjeka, bića izvode iz bitka, u njoj se čovjek prepoznaje u svojoj osebičnosti (An-sich-sein), priznaje bića po svojoj mjeri i istodobno u bogatstvu njihovih vrijednosti.

“Čovjek je proizvoditelj bića iz bitka. Zato Marx veže ljudsku slobodu, tj. bivstvovanje primjereno biti čovjeka uz smanjenje radnog dana". ${ }^{18}$

Čovjek se proizvodnjom potvrđuje u svojoj biti, a kao radnik upotrebljava svoju bit da bi mogao preživjeti. U proizvodnji istupa iz puke predmetnosti i prisutnosti stvari, kroz nju jest sloboda koja potvrđuje navlastitu otvorenost svojeg bića. S druge strane, postvarenje kroz rad moć preokreće u nemoć, njegovo biće se premeće u stvar među stvarima, robu među robama. Prema Sutliću, istinska proizvodnja je zapravo otkrivanje bitka koji se skriva iza otuđenja. Prevladavanje krize otuđenja moguće je samo ako se dospije u istinsku vremenitost čovjeka. Čovjek je povijestan i vremenit utoliko što se može oslobađati od prošlog i pukog sadašnjeg za buduće što kroz njih progovara.

"Povijest je otvaranje zatvorenog, oslobađanje od pukog prošlog i pukog sadašnjeg za buduće, po kojem ono što je bilo nije prošlo, a ono što jest nije sadašnje i svagdašnje, pozitivno, ustaljeno, ustajalo. Iza otuđenog-budućeg što još nije, iza otuđenog-sadašnjeg što samo sada trenutno jest - skrivena je istinska budućnost, koja nosi i pronosi istinsku bilost i istinsku suvremenost". ${ }^{19}$

Važno je da svijet rada postaje svijetom proizvodnje, tj. povijesnog sklopa jednokratne zgode misaonog bitka i smislenog vremena". ${ }^{20}$ Sutlić u knjizi Praksa rada kao znanstvena povijest distinkciju rada tematizira u okviru povijesnog mišljenja. Misleći mogućnost 'prave povijesne zgode', Sutlić misli i neotklonjivu, nužnu prisutnost rada kao takvog. Sve se uspostavlja radom, prevladava, u njemu se biće ponavlja i obnavlja, ukidajući i čuvajući svoje konačne momente. Nužno je pak

18 Sutlić, V. (1972) Bit i suvremenost, Sarajevo: Veselin Masleša, str. 25.

19 Isto, str. 42.

20 Sutlić, V. (1987) Praksa rada kao znanstvena povijest, Zagreb: Globus, str. 28. 


\section{ŽELJKO SENKOVIĆ}

iskušavanje još neiskušanih putova. Bitak zajednice se gradi, ali ujedno i razgrađuje, omogućavajući povijesne preokrete iz nove konstelacije/zgode bitka, vremena i čovjeka. Samosvjesnost i iznimnost ljudskosti odgovara samosvojnosti i jedinstvenosti povijesnog sklopa. U njoj i kroz jezik (u kazivanju) očituje se personalno-egzistencijalna bit čovjeka. U odnosima slobode i otvorenosti prekoračuje se rad kroz muku i otuđenje, a dolazi se u proizvodnju koja je uvijek zapravo 'proizvodnja svijeta'.

"Iz mraka nekazanoga i nekazljivoga povijesna zgoda u pružanju bitka i vremena omogućuje, ali ne primorava, bit čovjeka na primanje pokazanoga i njegov prijenos na su-bitak otvorenih ljudi priređujući zajednicu koja je usud koji ne odumire nego se povijesno mijenja i produbljuje". ${ }^{21}$

Marx u Kritici gothskog programa višu fazu komunizma vezuje uz rad kao prvu životnu potrebu, rad kroz koji čovjek povezuje druge i sebe u zajednicu, rad koji je autorstvo cjelovite ličnosti. To je mišljeno i u glasovitoj Marxovoj misli o umjetničkom karakteru (neotuđenog, proizvodnog) rada. No ovo, ma kako se danas iz neoliberalnog žrvnja novih robovanja čini utopističkim nedosanjanim snom, uvijek iznova upućuje na unutrašnju proliferaciju pojma rada (Rada), mišljenje mogućnosti toga što čovjek jest kao biće rada, o skokovitom prevođenju pojma rada u pojam proizvodnje (kao stvaralaštva i samostvaralaštva čovjeka kao bića odnosa), odnosno riječ je o iscrtavanju i ponovnom koloriranju klasičnog pojma prakse koji je današnjim pragmatističkokapitalističkim žrvnjem srozan u jednodimenzionalne vidike.

Misliti bit rada znači misliti 'oslobođenje rada'. To nije 'oslobođenje od', nego pronalaženje mogućnosti za epohalne koordinate u kojima će doći do iskonskog zbivanja punine života, prakse u kojoj se bivstvuje i misli polazeći od smisla ljudskosti, sebstva i Drugosti, a da bi zajednice i zajedništvovanja bilo. U današnjim vremenima kriza ${ }^{22}$ potrebno je tražiti temeljite i temeljne preobrazbe, jer su puke korekcije unutar suvremenih oblika rada kao robovanja takve da samo pogoršavaju izglede za preokret tradicije, za ukazivanje na slobodu kao nenadvladivi i neprekoračivi moment ljudskog kojeg nikakve palijativne i anestetične metode društva spektakla ne mogu spriječiti u ostvarenju. U tom smislu, pro-iz-vodnja bića iz bitka najavljena je u čovjeku-radniku. Riječ je o tome da se omogući drugačiji bitak-vrijeme-čovjek, s onu stranu otvorenog ili prikrivenog robovanja i izrabljivanja.

21 Sutlić, V. (1987) Praksa rada kao znanstvena povijest, Zagreb: Globus, str. 218 .

22 Samo neoliberalni ideolozi kao što je F. Fukuyama mogu smatrati da boljih vremena od današnjih nikada nije bilo. 


\section{ŽELJKO SENKOVIĆ}

"Mišljenje povijesnog života nezaobilazno pred-postavlja svijet znanstvenog rada, radne znanosti, jer ga je već uvijek omogućilo kao što je iz-zazvano njime u suvremenom odlučnom trenutku. Obrat svijeta je moguć samo iz njegova središta, ne iz oboda koji hoće da korigira vrtnju »kruga«. Kazivanje pri-goda života seže u srčiku realizirane metafizike rada, mito-logika kojeg nije posljednja moguća riječ. Može li život preskočiti svoju epohalnu, raz-dobnu sjenu u kojoj nestaje svijet, ili će se od nje odvratiti tek kad ustreba življenje kao uskok u svoje svjetlo?’.23

Pri mišljenju rada i prakse kod Marxa važno je ne stavljati naglasak na primat ekonomskog i opću proletarizaciju nego na ljudsku emancipaciju. Ljudi su kao proizvoditelji (bića iz bitka) politička bića u pravom smislu, jer je proizvodnja konstituens svake zajednice, te uvijek i samoproizvođenje. Povijest i život $u$ povijesti nisu dani nego zadani, pa je proizvodnja i kod Marxa i kod Arendt 'moć započinjanja' i 'carstvo slobode'. Sloboda pak nije suprotstavljena osnovnim životnim potrebama, nego počiva na njima.

"Praxis kao samoproizvođenje svrha je konačni način samoostvarenja koji je proces objektivacije subjekta. Dijalektička racionalnost na koju se ovo kretanje odnosi, upućuje dakle na pojedinca tako i na društvo u celini, ali na način otvorenog totaliteta koji dovodi u pitanje racionalnost samih granica sistema, kroz praxis kao mišljenje ali takođe i proizvodnju, koja postoji u meri u kojoj stvara umnu stvarnost". ${ }^{24}$ Suvremena stajališta o radu unutar horizonta ljudske prakse i uopće ljudskog bivstvovanja tiču se temeljnog i konstitutivnog momenta ljudskosti. Pa ipak, kako god promatrali praksu rada, to je uvijek i susret sa onim izmještenim izvan središta. Naime, uzeli rad iz aspekta nužde održanja života (H. Arendt) ili mnogovrsnih otuđenja koja su ujedno i put prevladavanja istog (K. Marx), riječ je o neprekoračivom djelatnom sklopu s kojim često nismo sigurni da li je moment neslobode ili slobode u nama. Atomizirani smo kao ustrojeni primjerci vrste animal laborans, ali su povijesnost i epohalnost mišljenja ono što poziva na traženje iskona. Tako je i sa središtem svih središta ljudskog: praksom rada koja vrhuni u proizvodnji svijeta. Klasična filozofija uvijek iznova poziva na dijalog s kojim ćemo razviti sluh za zagonetku slobode u nama. To da smo stvaralačka bića, samo je druga riječ za osmišljavanje svijeta. U tom smislu, pojam rada je transgresivan i upućuje na horizont mogućnosti istinskog ljudskog življenja i punine svjetovnosti u 'neiskazivoj smislenosti' (Žarko Paić), na što nas

23 Sutlić, V. (1987) Praksa rada kao znanstvena povijest, Zagreb: Globus, str. 158.

24 Koljević, B. (2007) Marxov pojam praxisa, Arhe, br. 7, Novi Sad: Filozofski fakultet, str. 47. 


\title{
ŽELJKO SENKOVIĆ
}

obvezuju o(be)smišljavanja u ovom 'ustrojenom svijetu' (Goran Starčević), u kojem premjeravamo bezdan (be)smisla.

\section{LITERATURA:}

Arendt, H. (1978) The Life of the Mind, New York: Harcourt Brace Jovanovich.

Arendt, H. (1996) Eseji o politici, Zagreb: Izdanja Antibarbarus. Arent, H (2009) Život duha, Beograd: Službeni glasnik.

Arendt, H. (1991) Vita activa, Zagreb: Biblioteka August Cesarec. Aristotel (1992) Nikomahova etika, Zagreb: Hrvatska sveučilišna naklada.

Marx, K (1953) Rani radovi, Zagreb: Naprijed.

Pöggeler, O. (1999) Heidegger u svom vremenu, Sarajevo: TKD Šahinpašić.

Rodin, D. (2012) Poraz prosvjetiteljstva, Zagreb: Naklada Breza.

Sutlić, V. (1972) Bit i suvremenost, Sarajevo: Veselin Masleša.

Sutlić, V. (1994) Uvod u povijesno mišljenje, Zagreb: Demetra.

Sutlić, V. (1987) Praksa rada kao znanstvena povijest, Zagreb: Globus.

Villa, D. R. (1996) Arendt and Heidegger. The Fate of the Political, Princeton: Princeton University Press.

\section{Željko Senković}

Josip Juraj Strossmayer University in Osijek, Faculty of Philosophy, Osijek, Croatia

\section{HOW TO THINK WORK AND PRACTICE}

\section{HANNAH ARENDT - VANJA SUTLIĆ - CONTEMPORARIES}

\begin{abstract}
Contemporary approaches to the terms of labour and praxis have multiple layers. This paper begins from the Aristotelian relation to labour in Hannah Arendt's work and her insistence on truly human action, separate from instrumental relations. Despite her thoughts on labour, which she reduced to the necessity to maintain life, it is the overall understanding of praxis as a space for diversion, possibility and freedom which is important in Arendt's work. One of Arendt's puzzling theses is her critique of Marx's understanding of labour. Differentiation between labour and work, in the spirit of Marx, is exquisitely developed in Vanja Sutlić's work. His texts show that the true work (as productio) is, in fact, revelation of a being hiding behind alienation. Hence, the fundamental moment of devising the world is the contemporary understanding of a man as a creative being.
\end{abstract}

Key words: Labour, Work, praxis, Hannah Arendt, Vanja Sutlić, Karl Marx 